\title{
Investigating Environmental Factors for Locating Mangrove Ex-situ Conservation Zones Using GIS Spatial Techniques and the Logistic Regression Algorithm in Mangrove Forests in Iran
}

\author{
Hasti Petrosian ${ }^{1}$,Afshin Daneh Kar ${ }^{1 *}$, Sohrab Ashrafi ${ }^{1}$, Jahangir Feghhi ${ }^{2}$ \\ ${ }^{1}$ Department of the Environment, Faculty of Natural Resources, University of Tehran, Iran \\ ${ }^{2}$ Department of Forestry, Faculty of Natural Resources, University of Tehran, Iran
}

Received: 10 April 2016

Accepted: 12 April 2016

\begin{abstract}
Along the coastal strip of tropical and subtropical regions, mangrove forests extend as one of the most productive coastal ecosystems. Iran is considered one of the most western coastal habitats of these communities in Asia. Unfortunately, in recent years, despite their economic and ecological importance, these forests have been threatened mainly due to human activities, which necessitate the need for protecting and developing these ecosystems. Ex-situ conservation, which aims to transfer a species to right place for preservation and development, is one of the most effective ways of protecting these forests. It is obvious that the successful transfer of a species in order to protect it as ex-situ conservation requires a comprehensive environmental assessment. The present paper employs a spatio-statistical methodology to delineate areas enriched with environmental parameters and weather factors necessary to support a mangrove ex-situ conservation plan in Hormozgan Province, Iran. With extensive effort in reviewing the related studies in the literature, we elicted a collection of 14 environmental and weather indicators critical to maintaining mangrove stands in a sustainable ecological environment. For screening the number of indicators to environmental variables with highest importance in our research, we used the Delphi method to quantify expert attitudes in order to develop a suitability index collection. Accordingly, an integrated application of GIS spatial analysis and a logistic regression algorithm were used to build an explicit spatial predictive model that evaluates the targeted area in terms of identified factors, thereby quantifying the potential of suitable zones for locating mangrove ex-situ conservation sites. Predictive performance of the developed model was evaluated based on Kappa index and omission error rate. According to our results, land proneness to a mangrove plantation has a high positive correlation with environmental attributes such as temperature fluctuation, land form, and mean tidal level, and has a negative correlation with slope and wave height. Our results should be considered advantageous for decision makers and planners in the field of mangrove ecosystems.
\end{abstract}

Keywords: mangrove forest, Avicennia marina, Hormozgan Province, Delphi, logistic regression

*e-mail: adanehkar@ut.ac.ir 


\section{Introduction}

Forested wetlands of mangrove ecosystems are the main vegetative cover of tropical coastlines. These places are rich and complex in ecology and are good primary locations for different types of birds and fish, as well as valuable areas for providing food and wood. Moreover, these ecosystems provide protection from typhoons and tornados [1].

In addition, as a pool of diversity, mangrove wetlands provide nursery habitats for a wide variety of prawns, shrimp, fish, crabs, and other crustaceans. Mangrove ecosystems are witnessing an astonishing rate and unprecedented scale of deforestation, mainly due to anthropogenic activities like expansion of aquaculture, wood overexploitation, and land use transformation [1-2]. Accordingly, it is estimated that during the next three decades unrestricted clear-cutting, aquaculture, and overexploitation of fisheries will be the greatest threats [2-3].Taking diverse services of mangrove ecosystems into account, depletion of mangrove reserves should be prohibited and the remaining mangroves need to be managed sustainablely [3]. Indonesia, Australia, Brazil, and Nigeria possess the largest mangrove reserves, accounting for $43 \%$ of the world's mangrove forests [2]. According to the Iranian agriculture bureau report in 2002, $93.37 \mathrm{~km}^{2}$ of Iranian shorelines are covered by mangrove forests [4] located at between $25^{\circ} 19^{\prime}-27^{\circ} 84 \mathrm{E}$. This area spans the three southern provinces of Iran (Bushehr, Hormuzgan, and Sistan and Balouchestan) and includes coastal boundaries of the Persian Gulf and Oman Sea. Avicennia marina (grey mangrove) is a dominant mangrove species in Iran [3].

Iran mangrove reserves have experienced a noticeable temporal decline in their distribution in recent decades [3]. The ongoing shrinking process of mangroves necessitates effective management in terms of mangrove forest rehabilitation. Mangrove forests occur as a function of several environmental parameters as well as climatic factors. These attributes can be processed as statistically explanatory variables in a spatial database. Their importance and degree of contribution in mangrove forest occurrence can be investigated through the integrated application of spatio-statistical modeling techniques. In this regard, statistical algorithms such as the logistic regression modeling approach in conjunction with GIS spatial techniques is of potential importance for estimating occurrence probability of mangrove stands. The implementation of spatially explicit probabilistic models has attracted noticeable research interest in recent years [5-7], in which the land is evaluated in terms of environmental and climatic factors (explanatory variables) that are necessary to support the establishment and maintenance of a mangrove plantation program. Integration of GIS spatial analysis and statistical modeling techniques can help managers and decision-makers in identifying suitable sites for mangrove plantations at minimum possible cost [8]. For example, Alongi stated that "people will continue to misuse mangrove forests with the present speed up to 2025 if the value of these forests as unique natural resources are not recognized, and plans for protecting them are not performed" [2].

According to the results of Elsebaie, although many worldwide projects have been developed to protect mangrove ecosystems, there has not been much success in performing these plans [6]. One of the reasons for these failures is wrongly locating areas suitable for mangrove plantations because locating the proper place for mangrove natural forests is an important factor in protecting and developing natural mangrove forests. Based on a study conducted by Abd-El Monsef et al., using satellite imagery interpretation, topographic maps, and soil maps for locating suitable sites for mangrove plantations, they indicated that "mangrove occurrence is correlated with environmental parameters, including air temperature, water temperature, salinity, tidal, wave energy, land proneness to flash-flooding, and soil suitability" [5]. In order to determine factors affecting mangrove forest occurrence, we investigated related studies on mangrove occurrence indicators in the literature (Table 3).

The purpose of this study is to achieve the following objectives:

1. Modeling the linkage between environmental attributes and mangrove presence on the basis of probability prediction values generated by the logistics regression model.

2. Identifying the explanatory variables linked to the possibility of mangrove occurrence.

3. Development of a spatial predictive model to detect suitable mangrove sites for ex-situ conservation programs.

\section{Material and Methods}

\section{Study Area}

We considered coastal boundaries along the northern Persian Gulf and Oman Sea Coast in Hormozgan Province as the study site. The surface area is approximately $1,000 \mathrm{~km}^{2}, 1,950 \mathrm{~km}$ long (parallel to the shoreline), and $500 \mathrm{~m}$ wide (Fig. 1). Mangrove forests along the Hormozgan coastal line occur between $25^{\circ} 25^{\prime} 51^{\prime \prime}$ to $27^{\circ} 18^{\prime} 55^{\prime \prime} \mathrm{N}$ and $52^{\circ} 39^{\prime} 41^{\prime \prime}$ to $59^{\circ} 14^{\prime} 2^{\prime \prime}$ E coordinates and dominated by A. marina species [3]. Table 1 shows the position of A. marina forests in Hormozgan.

\section{Indicator Screenings}

The Delphi method was applied to selected indicators with better performance in the study area. The Delphi technique is in essence a series of sequential questionnaires, or 'rounds', interspersed by controlled feedback and that seek to gain the most reliable consensus of opinion of a group of experts. It is a technique that is useful for situations where individual judgments must be tapped and combined in order to address a lack of agreement or incomplete state 


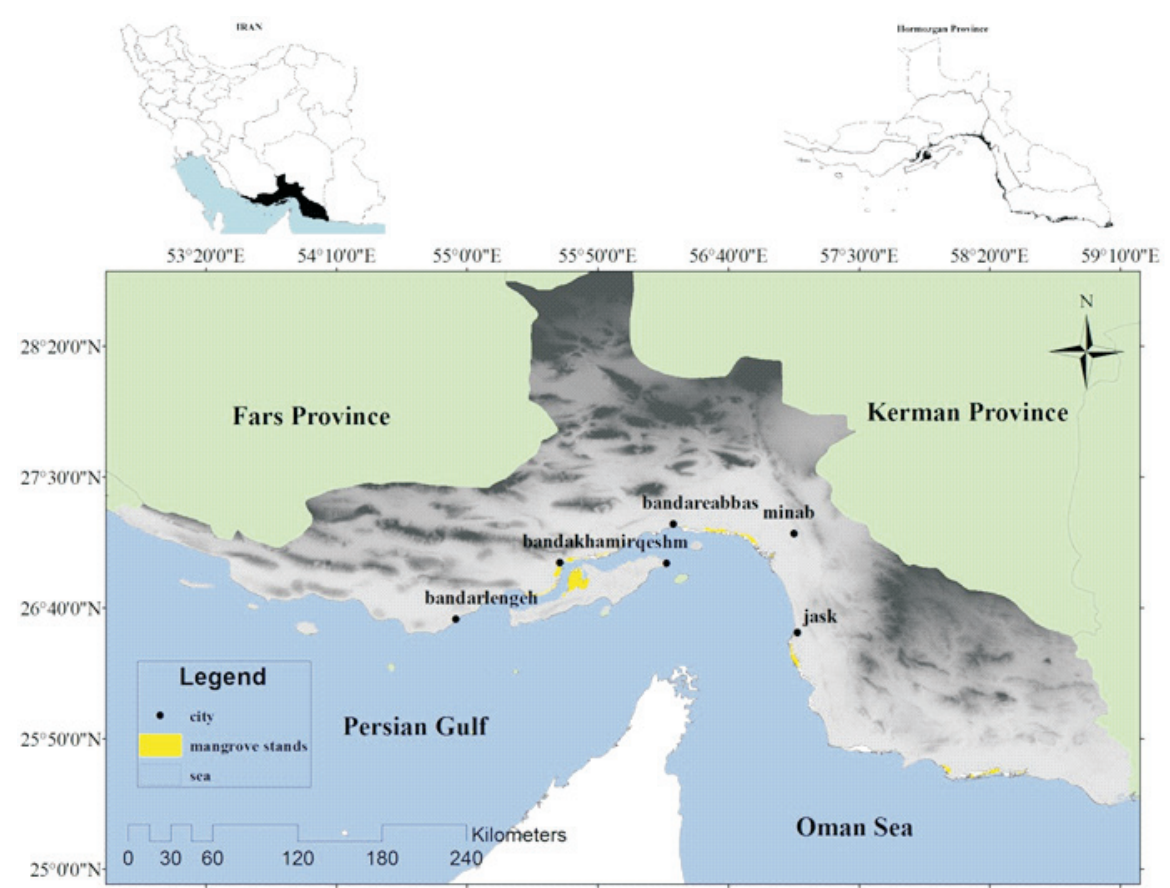

Fig. 1. Study area.

of knowledge [9]. In this study, 15 series of sequential questionnaires were analyzed in this way (15 experts).

\section{Preparing Maps}

Maps of the most important parameters that are assumed to make significant contributions to our study area were prepared as follows:

- Topographical data

The digital elevation model (DEM) of the study area obtained from the Maritime Organization of Iran (MOI) (with 30-m resolution) was interpreted through ArcGIS 9.3 package software to determine some important parameters, including slope (percent) and elevation maps for the backshore area of the coastline (Fig. 5).

- Landform data

We obtained a landform map of the study area from MOI. This map illustrated three different landforms of mud, sand, and rock in coastal regions of the province (Fig. 3).
- Climatology data

Climatology indices of the study area were extracted through data processing of five synoptic stations of weather monitoring that are located close to mangrove forests (Table 2 and Fig. 6)

- Wave height

Data of daily wave forecasts obtained from nine points were used to analyze wave height. We acquired these data from the MOI. The analyzed wave records belonged to a 10-year period from 2001 to 2014 (Fig. 7).

- Water Salinity

Water salinity data were provided from documents including national Iranian mangrove forest in 2012 and monitoring the coastal zone of Hormozgan Province in 2011.

- Mean tidal levels

Data of 12 selected sites were obtained based on the tide forecast table issued by the National Cartography Center (NCC) of Iran (Fig. 4).

- Soil properties

Table 1. Geographic position and area of Hormozgan Province mangrove forests (Zahed et al. 2010).

\begin{tabular}{|c|c|c|c|c|c|}
\hline \multirow{2}{*}{ No } & \multirow{2}{*}{ Province } & \multirow{2}{*}{ Region } & \multirow{2}{*}{ Area $\left(\mathrm{Km}^{2}\right)$} & \multicolumn{2}{|c|}{ Geographical position } \\
\cline { 4 - 6 } & & & & East longitude & North latitude \\
\hline 1 & Hormuzgan & Khamir Port & 10.5 & $56^{\circ} 77^{\prime}-56^{\circ} 83^{\prime}$ & $26^{\circ} 77^{\prime}-26^{\circ} 93^{\prime}$ \\
\hline 2 & Hormuzgan & Qeshm Island & 67.5 & $55^{\circ} 63^{\prime}-55^{\circ} 80^{\prime}$ & $26^{\circ} 75^{\prime}-26^{\circ} 93^{\prime}$ \\
\hline 3 & Hormuzgan & Kouleghan Areas & 1.00 & $56^{\circ} 51^{\prime}-56^{\circ} 58^{\prime}$ & $27^{\circ} 16^{\prime}-27^{\circ} 18^{\prime}$ \\
\hline 4 & Hormuzgan & Tiyab Area & 1.30 & $56^{\circ} 77^{\prime}-56^{\circ} 83^{\prime}$ & $27^{\circ} 11^{\prime}-27^{\circ} 14^{\prime}$ \\
\hline 5 & Hormuzgan & Sirik & 4.86 & $57^{\circ} 06^{\prime}-57^{\circ} 12^{\prime}$ & $26^{\circ} 30^{\prime}-26^{\circ} 44^{\prime}$ \\
\hline 6 & Hormuzgan & Jask Area & 2.00 & $57^{\circ} 80^{\prime}-57^{\circ} 82^{\prime}$ & $25^{\circ} 69^{\prime}-25^{\circ} 70^{\prime}$ \\
\hline
\end{tabular}




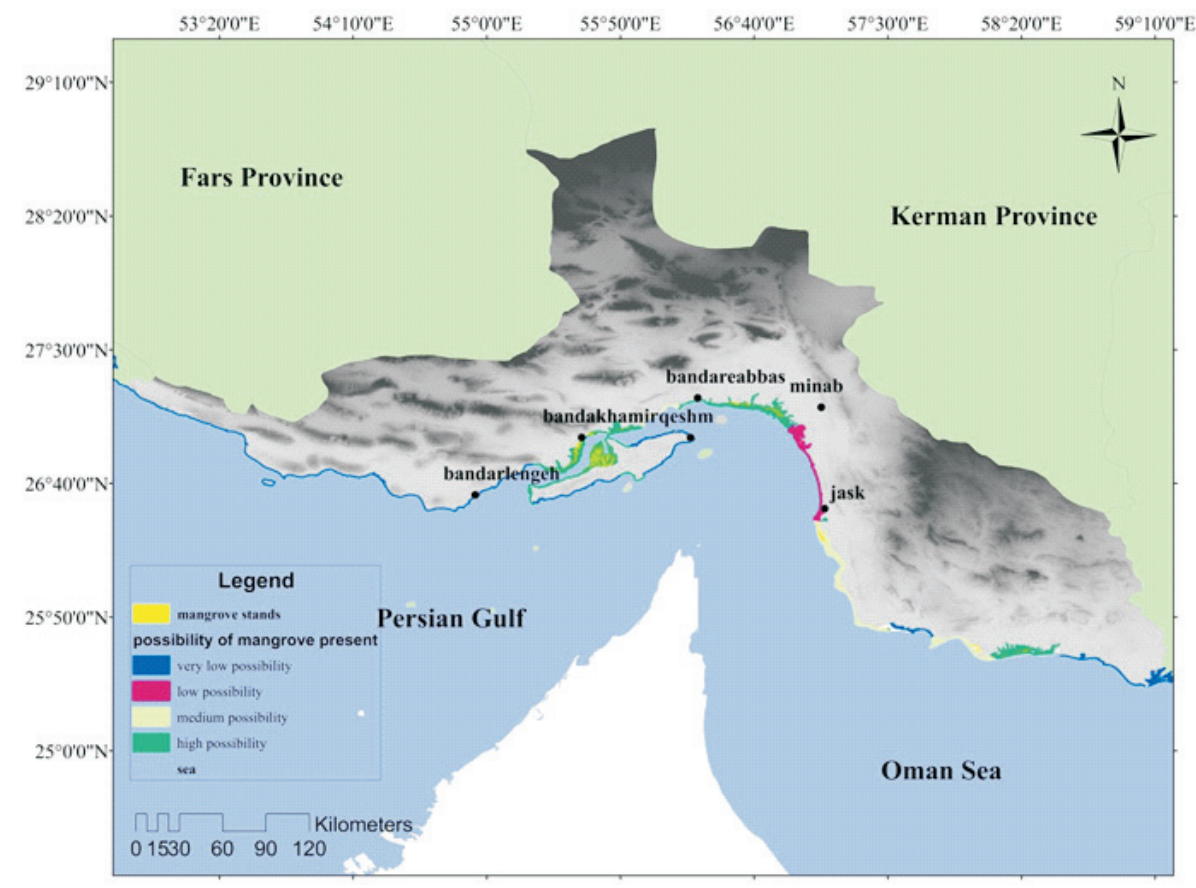

Fig. 2. Results of logistic regression.

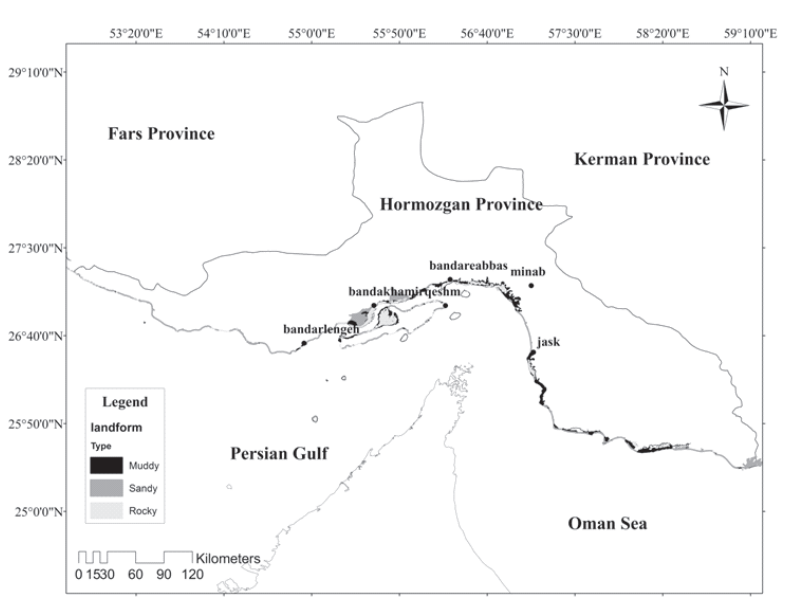

Fig 3. Land form types in study area.

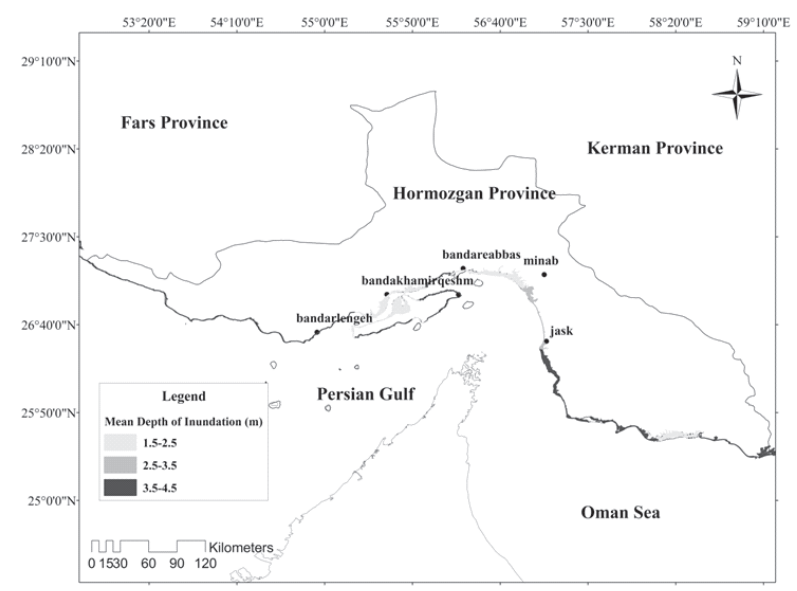

Fig 4. Mean tidal level in study area.
Data of salinity of soil was obtained from previous studies such as the Iranian mangrove forest document in 2012 and monitoring and modeling of the Hormozgan Province coastline in 2011.

All input data layers were imported into a GIS environment and then an inverse distance weighting (IDW) algorithm was used for data interpolation [10]. The input layers were transformed into $100 \mathrm{~m} \times 100 \mathrm{~m}$ 1:25000-scale grid and co-registered to the same extent by the source of Universal Transverse Mercator datum and a WGS 84 projection system.

\section{Statistical Analysis}

- Random Sampling

From the total available cells, 5\% of random sampling

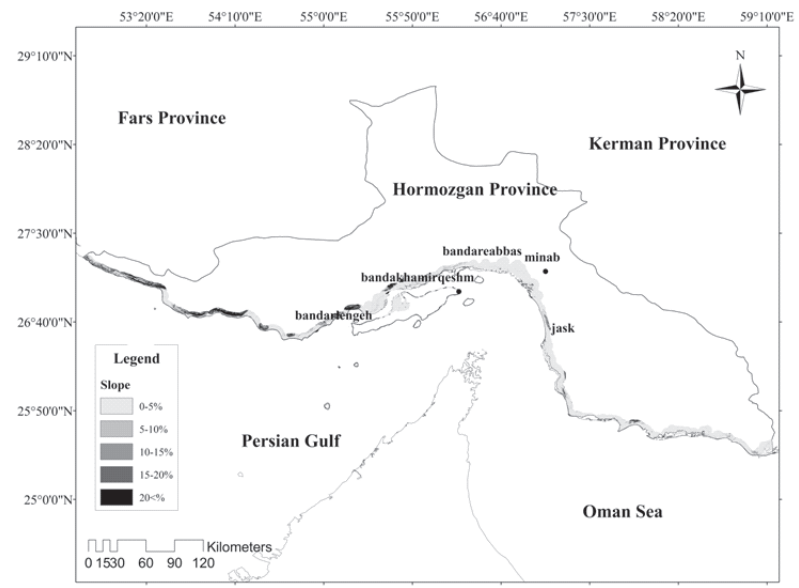

Fig. 5. Slope parameter in study area. 


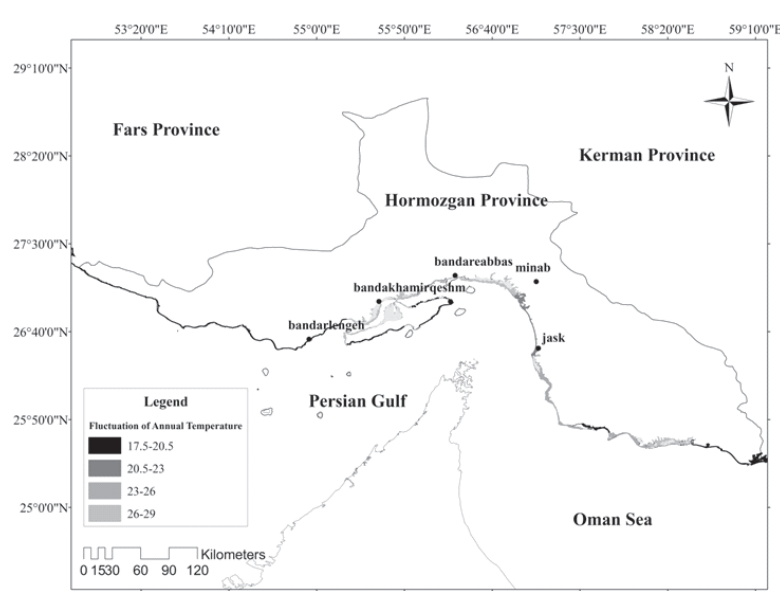

Fig 6. Fluctuation of annual temperature in study area.

points were overlaid with all selected index layers (distributed across the entire region). Only those sampled grid cells that appeared to retain $100 \%$ of their natural forest cover were classified as mangrove forest presence (1). Otherwise, they were classified as mangrove forest absence (0). Accordingly, digital values of environmental settings in terms of the presence and absence of locations of mangroves were extracted.

- Correlation analysis

In order to identify predictive variables with most predictive value for developing a logistic regression model, parameters were examined in terms of correlation and dependency. The correlation analysis was performed because the overlaid data can lead to exaggerated results, and an insufficient number of variables can result in missing information. Therefore, simple correlations were established between each pair of variables. When the correlation value exceeded 0.8 , only one variable was used for further analysis [11].

- Logistic regression-based model building

The purposes of model development are: 1) to assess the relative influence of 14 explanatory variables on probability [12] of mangrove forest occurrence, and 2) to predict the probability of mangrove occurrence for the future. Therefore, we developed a logistic regression model in order to model the linkage between dependent variables (the presence and absence of mangroves) and independent variables (environmental parameters).

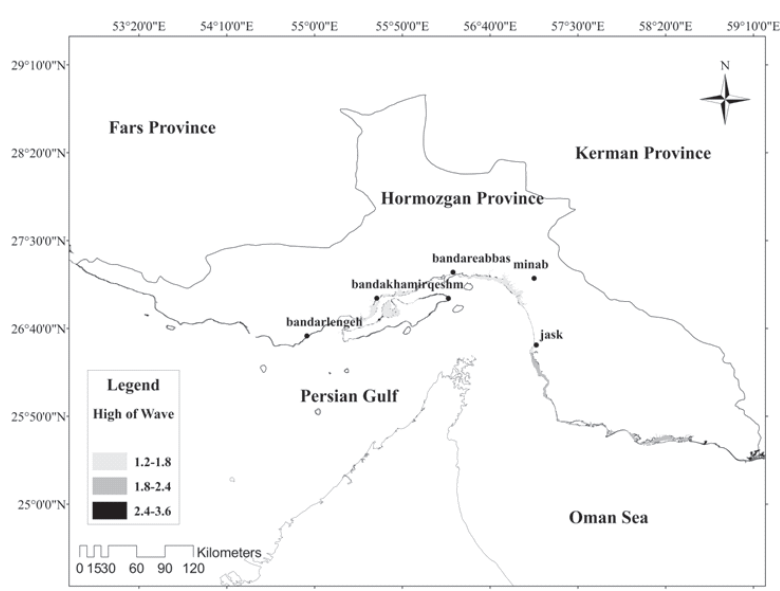

Fig 7. Wave height in study area.

Formula 1: Logistic regression model for binary data.

$$
Y=\frac{\operatorname{Exp}\left(b_{0}+b_{1 x_{1}}+b_{2 x_{2}}+\ldots+b_{n x_{n}}\right)}{1+\operatorname{Exp}\left(b_{0}+b_{1 x_{1}}+b_{2 x_{2}}+\ldots+b_{n x_{n}}\right.}
$$

...where: $Y$ Is the expected probability that the outcome is present, $X_{1}$ through $X_{\mathrm{p}}$ are distinct independent variables, and $b_{0}$ through bp are the regression coefficients.

- Model performance evaluation

For evaluating model performance we used methods that included Kappa index and classification table methods.

\section{Results and Discussion}

\section{Literature Review}

Considering the results of investigating 20 studies from Iran and other parts of the world, three effective criteria and 23 indices were identified for detecting suitable sites for developing Avicennia marina forests (Table 3 ).

\section{Indicator Screening Results}

According to the results of the Delphi method, maximum annual precipitation, average temperature in the hottest month, maximum temperature, evaporation, water

Table 2. Synoptic stations.

\begin{tabular}{|c|c|c|c|c|}
\hline \multirow{2}{*}{ Synoptic station } & \multirow{2}{*}{ Elevation from sea level } & Period of information (years) & \multicolumn{2}{|c|}{ Geographical position } \\
\cline { 3 - 5 } & & & East longitude & North latitude \\
\hline Jask & 5 & 21 & $25^{\circ} 38^{\prime}$ & $57^{\circ} 46^{\prime}$ \\
\hline Minab & 27 & 21 & $27^{\circ} 07^{\prime}$ & $57^{\circ} 06^{\prime}$ \\
\hline Bandar Abbas & 10 & 22 & $27^{\circ} 13^{\prime}$ & $56^{\circ} 22^{\prime}$ \\
\hline Gheshm & 6 & 22 & $26^{\circ} 55^{\prime}$ & $55^{\circ} 55^{\prime}$ \\
\hline Bandar Lenge & 12 & $26^{\circ} 32^{\prime}$ & $54^{\circ} 50^{\prime}$ \\
\hline
\end{tabular}


Table 3. Criteria and indices that extract from studies.

\begin{tabular}{|c|c|c|}
\hline Criteria & Indices & References \\
\hline \multirow{10}{*}{ 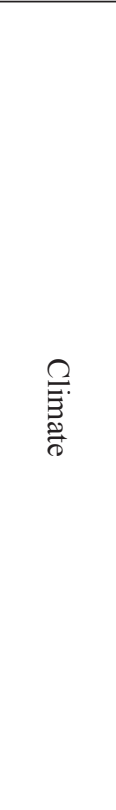 } & $\begin{array}{l}\text { Mean annual } \\
\text { perception }\end{array}$ & {$[26-30,3]$} \\
\hline & $\begin{array}{l}\text { Minimum annual } \\
\text { perception }\end{array}$ & {$[31-32,3]$} \\
\hline & $\begin{array}{l}\text { Maximum annual } \\
\text { perception }\end{array}$ & {$[32,3]$} \\
\hline & $\begin{array}{l}\text { Average temperature in } \\
\text { the coldest month }\end{array}$ & {$[30-29,3]$} \\
\hline & $\begin{array}{l}\text { Average temperature in } \\
\text { the hottest month }\end{array}$ & {$[30,5,3]$} \\
\hline & $\begin{array}{l}\text { Mean annual } \\
\text { temperatures }\end{array}$ & {$[27,29,33,30,3]$} \\
\hline & $\begin{array}{c}\text { Minimum and } \\
\text { Maximum temperatures }\end{array}$ & {$[34,3,32]$} \\
\hline & $\begin{array}{l}\text { Varying of annual } \\
\text { temperatures }\end{array}$ & {$[3,35]$} \\
\hline & Evaporation & {$[26,29]$} \\
\hline & Kind of Climate & {$[28,33,26,35,3]$} \\
\hline \multirow{8}{*}{ 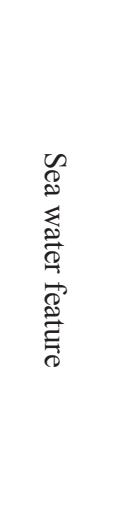 } & Tidal range & {$[28,16,26,34,5]$} \\
\hline & $\begin{array}{l}\text { Mean depth of tidal } \\
\text { inundation }\end{array}$ & {$[20,33,36]$} \\
\hline & Wave height & {$[20,16]$} \\
\hline & Water salinity range & $\begin{array}{c}{[31,34-37,34,35,} \\
39,20]\end{array}$ \\
\hline & Water $\mathrm{pH}$ & $\begin{array}{c}{[34,37,38,20,} \\
36]\end{array}$ \\
\hline & Water EC & [37-38] \\
\hline & Water temperature & {$[35,39]$} \\
\hline & Elements of water & {$[26]$} \\
\hline \multirow{5}{*}{$\begin{array}{l}\vec{D} \\
\stackrel{0}{0} \\
\overrightarrow{0} \\
\overrightarrow{0} \\
\stackrel{0}{0} \\
\overrightarrow{0}\end{array}$} & Slope & {$[16,20]$} \\
\hline & Topography & {$[26]$} \\
\hline & Landform & $\begin{array}{c}{[33,31,20,28,} \\
38,40,41] \\
\end{array}$ \\
\hline & Soil salt content & $\begin{array}{c}{[33,37,38,20,} \\
36,42,5,19]\end{array}$ \\
\hline & Soil pH & $\begin{array}{c}{[37,38,40-42,20,} \\
35,5]\end{array}$ \\
\hline
\end{tabular}

$\mathrm{pH}$, water EC, elements of water, water temperature, and soil $\mathrm{pH}$ must be eliminated, and mean annual precipitation, minimum annual precipitation, average temperature in the coldest month, mean annual temperatures, minimum temperatures, variation of annual temperatures, climate type, tidal range, mean depth of tidal inundation, wave height, water salinity range, slope, topography, and landform are selected variables to choose suitable areas for developing mangrove forests.

Below we present the most important parameters extracted from the mentioned articles and range of each of these parameters in the mangrove forests along the coasts of the Persian Gulf and Gulf of Oman (Hormozgan Province).
Table 4. Effective model development.

\begin{tabular}{|c|c|c|c|}
\hline Variable & Value & P-Value & $\begin{array}{c}\text { Standard } \\
\text { error }\end{array}$ \\
\hline Intercept & -7.7 & 0.001 & 0.311 \\
\hline $\begin{array}{c}\text { Fluctuation of annual } \\
\text { temperature }\end{array}$ & 0.56 & 0.003 & 0.069 \\
\hline Landform & 2.2 & 0.03 & 0.062 \\
\hline Slope & -1.2 & 0.009 & 0.018 \\
\hline High of wave & -5.3 & 0.013 & 0.2 \\
\hline $\begin{array}{c}\text { Mean depth of tidal } \\
\text { inundation }\end{array}$ & 0.6 & 0.002 & 2.1 \\
\hline
\end{tabular}

\section{Description of the Selected Parameters}

\section{- Climatic Criteria}

These criteria include the sub-criteria of precipitation, temperature, evaporation, and climate type, which are discussed below.

\section{- Precipitation}

Amount, duration, and distribution of rainfall influence on the development of flora and fauna. While mangroves are not directly affected by rainfall, rainfall indirectly has an important effect on the establishment of mangroves [5]. Rainfall washes excess salt from the soil and improves the growth of mangroves. In this study, the indicators of mean annual rainfall and minimum annual rainfall were identified as two significant indicators influencing rainfall. Mangrove communities along the Hormozgan coastline occur in an area with mean annual rainfall ranging from 126 to $204 \mathrm{~mm}$ (160 $\mathrm{mm}$ in average), and in the last 22 years received at least $16 \mathrm{~mm}$ of rainfall.

\section{- Air temperature}

Areas with high annual temperature and temperature fluctuations less than $10^{\circ} \mathrm{C}$ are suitable sites for mangroves. At lower temperatures, tree size, leaf area index, and compounds synthesized by plants decrease [13]. Avicenia has a high tolerance to temperature fluctuations, and this is reflected by their distribution at high and low latitudes worldwide [14]. Five indices of mean minimum temperature of the coldest month, annual temperature fluctuations, absolute minimum temperature, mean monthly temperature, and climate type are among the identified indices in this study. Based on the long-term mean monthly temperature index, this temperature ranges from 26.71 to $28.65^{\circ} \mathrm{C}$ (with an average of $27.5^{\circ} \mathrm{C}$ ) along the Hormozgan coastline.

In Hormozgan coasts, mangrove communities tolerate mean minimum temperature in the coldest month, ranging from about 12 to $14^{\circ} \mathrm{C}$ (the mean minimum temperature in the coldest month along the coastline is $13.76^{\circ} \mathrm{C}$ ) and the absolute minimum temperature recorded in the area is about $2.8^{\circ} \mathrm{C}$. Temperature fluctuations serve as an important factor in the distribution of mangrove forests, 
Table 5. Areas of suitable zones for planting A. marina variables.

\begin{tabular}{|c|c|}
\hline Township & Areas(ha) \\
\hline Bandar Abbas & 5,600 \\
\hline Sirik & 5,500 \\
\hline Jask & 2,800 \\
\hline Sirik & 2,300 \\
\hline Gheshm & 840 \\
\hline Bandar Lenge & 20 \\
\hline Sum & 17,060 \\
\hline
\end{tabular}

as the majority of mangrove species only grow in areas where temperature fluctuation is less than $10^{\circ} \mathrm{C}$ [13]. Temperature fluctuations in the range of the distribution of mangroves along the Hormozgan coastline range from 17 to $50^{\circ} \mathrm{C}$, with an average of $29^{\circ} \mathrm{C}$.

- Climate type

One of the most important factors in distributing and establishing mangroves is climate [15], so that mangroves are limited to the coastal areas of tropical and subtropical regions and are not present in other climatic conditions [3].

- Criteria of seawater characteristics

Sub-criteria of his criteria effective in distribution of mangroves include wave, tidal zone, the amount of flooding during tide, and the salinity range of sea water.

- Waves

Mangroves are located in areas protected from the effects of waves, so the first condition for the growth of mangroves is the existence of an area with minimum water movement [16]. Maximum wave height recorded in the Hormozgan coastal area in a 21-year period between 1992 and 2013 ranges from $2.1 \mathrm{~m}$ to $6.3 \mathrm{~m}$.

- Tidal zone

In almost all definitions for mangroves, these forest are considered plants belonging to the tidal zone. The results of this study show that Hormozgan mangrove communities are distributed in the coastal areas with minimum tidal zones of at least $150 \mathrm{~m}$, and these forests are not capable of growing in narrow coats of widths less than $150 \mathrm{~m}$.

- Salinity range of seawater

Mangroves generally are more dense in areas with low salinity, as studies have shown that in high salinity mangroves consume more energy to maintain water and proper concentrations of ions, with energy allocated for growth and primary production. The salinity range in Hormozgan estuaries vary from 38 to $48 \mathrm{mg} / \mathrm{l}$.

- Maximum flooding during tide

When the amount of flooding habitats is not proportional to species tolerance, the species cannot distribute. Studies of tide height in tidal stations showed that the highest mean annual tide occurs in the central Hormozgan coasts with the highest and the lowest heights recorded as 4.5 and $1.8 \mathrm{~m}$.

\section{Criterion of Land Characteristics}

- Texture

Soil texture is an important factor affecting the mangrove ecosystem. In terms of particle size distribution, mangroves demand fine-grained soils [6]. The majority of the study area is characterized by sandy and silty-textured soils.

- Slope

Mangroves generally grow in low-slope and flat areas with large tidal range and low activity of waves, and the structure of the forests is affected by the effect of slope on tidal range [17]. Obviously, as the slope decreases, tide encompasses wider areas and leads to increased distribution of mangroves [18]. Bed slope of the study area ranges from $0 \%$ to $15 / 5$.

- Soil salinity

Salinity plays an important role in the distribution of the species, production, and growth of mangrove forests. Soil salinity affects the growth of plants through photosynthesis and respiration, and high salinity causes plants to be dwarf-sized [19]. Soil salinity in this province varies from 60 to $70 \mathrm{ppt}$.

\section{Results of Spatial Analysis}

Fourteen raster maps of continuous surfaces were generated using the IDW interpolation method. Fourthousand six-hundred random samples (from presence and absence locations of mangrove forests) were selected to extract information from raster maps of our driving forces. The values were entered into the Minitab 16 software and the correlations between each pair of variables were investigated.

\section{Results of Correlation}

Correlation analysis revealed that there is a strong correlation among mean annual precipitation, minimum annual precipitation, average temperature in the coldest month, minimum temperatures, and fluctuation of annual temperatures. Consequently, we eliminated correlated variables from the model development process, and only fluctuation of annual temperatures as a highly contributing factor in predicting the probability of mangrove occurrence was included. Finally, climate type with invariable attributes across the entire study area were also omitted from logistic model building.

\section{Results of Logistic Regression Modeling}

A logistic regression model was created according to 14 attributes of predictive variables related to the locations of sampling points. In this regard, the dependent variable was either a presence or absence event $(1=$ mangrove forest presence and $0=$ mangrove forest absence), and environmental parameters serve as independent variables. The relative importance of each variable was assessed through regression coefficient. 
$P$-values of predictive variables, fluctuation of annual temperature, landform, slope, wave height, and mean depth of tidal inundation were less than 0.05 ; therefore, these indicators can estimate the occurrence of $A$. marina. Table 4 and Formula 2 represent the significant variables with their $p$-values for predicting mangrove occurrence.

Formula 2

$Y=\frac{\operatorname{Exp}(-7.7+0.56 F T+2.2 L-1.2 S-5.3 H W+0.6 D T)}{1+\operatorname{Exp}(-7.7+0.56 F T+2.2 L-1.2 S-5.3 H W+0.6 D T)}$

...where:

$Y$ - Probability of mangrove occurrence

$F T$ - Fluctuation of annual temperature parameter

$L$ - Landform parameter

$S$ - Slope parameter

$H W$ - Height of wave parameter

$D T$ - Mean depth of tidal inundation parameter

\section{Model Performance Evaluation}

Model performance evaluation indicated 0.801 and $2 \%$ for Kappa index and omission error, respectively.

\section{Running the Logistic Regression Model}

In this study we executed our predictive model based on GIS data layers (Fig. 2). The result showed that only $17 \%$ of the Hormozgan coastline (with probability of 60 to $90 \%$ ) was suitable for planting $A$. marina. In addition, most of the suitable areas are located in the Sirik and Bandar Abbas townships coastline. Table 5 presents areas of suitable zones in different parts of the province.

Based on results, wave height was an indicator with the highest predictive power for mangrove forest presence, which is negatively correlated with mangrove occurrence probability. This means that the probability of A. marina occurrence increases as wave height decreases. This finding is compatible with the study of Kamali and Hashim, who concluded that "wave action and erosion were among the most important factors influencing the possibility of mangrove seed survival." Also, Kamali and Hashim considered surges to be the only reason to convert Malaysia's west coast, which was covered with mangrove forests [16]. If the mangrove seeds are not planted in suitable places, they might be uprooted or washed away by strong waves, rain, or waterflow. Low wave energy is better for the mangrove to root strongly in the soil. Gilamn and his colleague have reported that "in rehabilitation and restoration sites, wave action should be regarded as an important mangrove uprooting cause, which ultimately can prohibit mangrove seedlings" [20]. Neinavaz and her colleague concluded that "severe waves and extreme tidal action can uproot mangroves and decrease growth" [21].

In addition, Zahed and his colleague also determined severe waves to be the main cause for the absence of Avicennia marina in many mangrove habitats of Iran. It is recommended, if necessary, to create structures such as breakwaters in planting areas to protect the seedlings [4].

Fluctuation in annual temperature was scored as the second contributing factor and represented a direct relationship to A. marina existence probability. Data analysis of coastal weather stations showed that temperature fluctuation in the coastal province of Hormozgan is about $24^{\circ} \mathrm{C}$. This result is also verified by other studies, including Morrisey and his colleague [22], Krauass and his colleague [23], Petrosian and her colleague [3], and Balachandran [24], who confirmed the importance of temperature for mangrove distribution, productivity, and reproduction.

Fluctuations in annual temperature in the coastal province of Hormozgan is high, and higher than fluctuations in annual temperatures of most of the mangrove habitats in the world, which represents the high tolerance of Avicennia marina against temperature changes and drought. So this species is among the most suitable species in terms of Iran's climatic conditions, and introducing other mangrove species for planting to this region will likely fail due to an inability to withstand temperature changes.

Muddy landform is the third factor linked to mangrove occurrence likelihood, which had been reported as an effective factor in similar studies, including Zahed and his colleague [4] and Monsef and his colleague [5]. One reason for the development of mangroves on muddy soil is the ability of these soils to absorb phosphates, and since soil phosphorus is one of the major factors in the growth of mangrove forest, mangrove forests prefer muddy soils as regions for their development [18].

Hinterland slope has not been regarded as as an important variable in the majority of studies conducted in other parts of the world, but it was considered an influential variable in this study. Slope indicated a negative relationship with $A$. marina existence probability. Areas with a low percentage of backshore slope are correlated with increased river stream and low speed, which create appropriate conditions for mangrove seedlings [3].

Areas with high slope cause a return to breaking waves with higher force, while the waves in areas with low slope (which generally constitute important areas of biological communities) distribute and lose their power [2].

The forth factor is the mean depth of tidal inundation, which demonstrated a positive correlation with the likely presence of mangroves. In general, if the tidal range of the coast is high, the possibility of a mangrove forest will increase because greater tidal range reduces the possibility of sediment formation [5]. This parameter prevents coastal salinity to the death threshold and this mechanism is vital for mangrove forests, which are arbitrary halophytes [3].

Model performance was evaluated and calculated using Kappa and omission error. The results were 0.801 and $2 \%$ for Kappa index and omission error, respectively, which denoted high accuracy of the developed logistic model in successfully predicting mangrove occurrences [11]. Predicted probabilities of mangrove occurrence in the study indicated that highly potential lands for a 
mangrove plantation are located in Bandar Abbas and Sirik townships. Consequently, the priority of these areas in establishing new mangrove plantation programs is evident. In addition, the cost of mangrove restoration and planting projects can be considerable. Therefore, these projects should be designed in advance to achieve success and to avoid wasting large amounts of money [17]. In most cases, direct human disturbance is the cause of mangrove degradation, so the risk of human-induced disturbance in the restoration and development sites must be eliminated before commencing plantation programs [25].

\section{Conclusions}

In our study, spatial analysis techniques and a logistic regression model provided a valid predictive model of mangrove occurrence as a function of several environmental and weather parameters. The results of our study are advantageous for mangrove management plans and can be beneficial for decision makers to identify suitable lands for mangrove existence at minimum expense.

\section{Acknowledgements}

The authors wish to thank MOI and NCC for providing the data implemented in this study.

\section{References}

1. WALTERS B.B., RONNBACK P., KOVACS J.M., CRONA B., HUSSAIN S.A., BADOLA R., PRIMAVERA J.H., BARBIERF E., DAHDOUH-GUEBAS F. Ethnobiology, socio-economics and management of mangrove forests: A review. Aquatic Botany, 89, 220, 2008.

2. ALONGI M. Present state and future of the world's mangrove forests. Environ Conserv, 29 (3), 331, 2002.

3. PETROSIAN H., ASHRAFI S., DANEHKAR A., FEGHHI J. The use of logistic regression to identify climate factors affecting the distribution of mangrove forest of Hormozgan province, Iran. Journal of Natural Environment, 67 (2), 135, 2014.

4. ZAHED M.A., RUHAN F., MOHAJERI S. An over view of Iranian mangrove ecosystem, northern part of the Persian Gulf and Oman Sea. Acta Ecologica Sinica, 30 (4), 240, 2010.

5. MONSEF H., AYMAN S., SCOT E.S. Locating suitable mangrove plantation sites along the Saudi Arabia Red Sea Coast. Journal of African Earth Sciences, 83, 1, 2013.

6. ELSEBAIE I.H., ALGUIB A., GARNI D. The Role of Remote Sensing and GIS for Locating Suitable Mangrove Plantation Sites along the Southern Saudi Arabian Red Sea Coast. International Journal of Geosciences, 4, 471-479, 2013.

7. COLEMAN J.M., HUH O.K, BRAUD D.W. Wetland loss in world deltas. Journal of Coastal Research, 24, 1, 2008.

8. PEARCE J., FERRIER S. Evaluating the predictive performance of habitat models developed using logistic regression. Ecological Modelling, 133, 225, 2010.

9. SAFAVIAN A., AMANI M. Multi-criteria analysis, a good way to end the value of ecosystem services in the environmental assessment process. Science Road Journal, 3 (8), 13, 2015.
10. CHEN F.W., CHEN-WUING L. Estimation of the spatial rainfall distribution using inverse distance weighting (IDW) in the middle of Taiwan. Paddy Water Environment Journal, 10, 209, 2012.

11. KAMYAB H.R., MAHINY A., HOSEINI S.M., GHOLAMALIFARD M. Modeling urban growth effects on landscape structure in Gorgan city area. Spring, 1 (2), 99, 2013.

12. SARHANGZADEH J., YAVARI A.R. HEMAMI M.R., JAFARI H.R., ESFANDABAD B. Habitat suitability modeling for wild goat (Capra aegagrus) in a mountainous arid area, central Iran. Caspian J. Env. Sci, 11 (1), 41, 2013.

13. OMO-IRABOR O.O., OLOBANIYI S. B., AKUNNA J., VENUS V., MAINA J.M., PARADZAY C. Mangrove mulnerability modeling in parts of western Niger delta, Nigeria using satellite images, GIS techniques and spatial multi-criteria analysis (SMCA). Environmental Monitoring Assessment, 178, 39, 2011.

14. QUISTHOUDT K., SCHMITZ N., DAHDOUH-GUEBAS F., ROBERT E., KOEDAM N. Temperature variation among mangrove latitudinal range limits worldwide, Trees, 26, 1919, 2012

15. HESHAM A.M., AYMA S., SCOT S. Locating suitable mangrove plantation sites along the Saudi Arabia Red Sea Coast. Journal of African Earth Sciences, 83, 1, 2013.

16. KAMALI B., HASHIM R. Mangrove restoration without planting. Ecological Engineering, 37 (2), 387-391, 2010.

17. LEWIS R.R. Ecological engineering for successful management and restoration of mangrove forests. Ecological Engineering, 24, 403, 2005.

18. KATHIRESA K., RAJENDRAN N. Coastal Mangrove Forests Mitigated Tsunami. Estuarine Coastal and Shelf Science, 65, 601, 2005.

19. PERERA K., AMARASINGHE M., SOMARATNA, S. Vegetation structure and species distribution of mangroves along a soil salinity gradient in a micro tidal estuary on the north-western coast of Sri Lanka. American Journal of Marine Science, 1 (1), 7, 2013.

20. GILMAN E., ELLISON J. Efficacy of alternative low-cost approaches to mangrove restoration, American Samoa. Estuaries and Coasts, 30 (4), 641, 2007.

21. NEINAVAZ E., BARATI A., BROWN J., ETEZADIFAR F., EMAMI B. Effects of nest characteristics and black rat Rattus rattus predation on daily survival rates of great egret Ardea alba nests in mangrove forest in the Hara Biosphere Reserve, the Persian Gulf. Wildl. Biol., 19 (3), 240-, 2013.

22. MORRISEY D.J., SWALES A., DITTMAN S., MORRISON M.A., LOVELOCK C.E., and Marine Biology, 48, 43, 2010.

23. KRAUSS K.W., LOVELOCK C.E., MCKEE K.L., HOFFMAN L., EWE S.M.L., SOUSA M.P. Environmental drivers in mangrove establishment and early development: A Review. Aquatic Botany, 89, 105, 2008.

24. BALACHANDRAN N., KICHENAMOURTHY S., MUTHUKUMARA, J., JAYAKANTHAN M., CHANDRASEKAR S., PUNETHA A., SUNDAR D. Diversity of true mangroves and their associates in the Pondicherry region of South India and development of a mangrove knowledgebase. Journal of Ecology and the Natural Environment, 1 (5), 99, 2009.

25. ANGELELL P., SAFFACHE P. Some remarks on Mangroves in the Lesser Antilles. Journal of Integrated Coastal Zone Management 13 (4), 473, 2013.

26. ZALDIVAR- JIMENEZ M.A., HERRERA-SILVERIA J.A., TEUTLI-HERNANDEZ C., FRANCISCO A. Conceptual Framework for Mangrove Restoration in the Yucatán Peninsula. Ecological Restoration, 28 (3), 333, 2010. 
27. WANGONDU V.W., KAIRO J.G., KINYAMARIO J.A., MWAURA F.B., BOSIRE J.O., DAHDOUH-GUEBAS F., KOEDAM N. Phenology of Avicennia marina (Forsk.) Vierh in a disjunctly-zoned mangrove stand in Kenya. Journal of Marine Science, 9 (2), 135, 2010.

28. RAKOTOMAVO A., FROMARD F. Dynamics of mangrove forests in the Mangoky river delta, Madagascar, under the influence of natural and human factors. Forest Ecology and Management, 259 (6), 1161, 2010.

29. HE B., LAI T., FAN H., WANG W., ZHENG H. Comparison of flooding-tolerance in four mangrove species in a diurnal tidal zone in the Beibu gulf. Estuar. Estuarine Coastal and Shelf Science, 74, 254, 2007.

30. ERFANI M., NOURI G.R., DANEHKAR A., MARVIMOHAJER M.R., MAHMOUDI B. Vegetative parameters of mangrove forest on the Govater bay in southeast of Iran. Journal of Taxonomy Biosystematics. 1 (1), 33, 2009.

31. SAIFULLAH S., GUL S., RASSOL F. Anomalous aerial roots in Grey mangroves of an arid. Pakistan J Bot, 36 (2), 463, 2004.

32. SAFA H., DANEHKAR A., KAMRANI E. Study on the mangrove forest structure at the Koolaghan, Tiyab and Kolahi regions in the strait of Hormoz (north part of Persian Gulf). Envromental Sciences, 11, 1, 2006.

33. ROBERT M.R.E., KOEDAM N., BEEKMAN H., SCHMITZ N. A safe hydraulic architecture as wood anatomical explanation for the difference in distribution of the mangroves Avicennia and Rhizophora. Functional Ecology, 23, 649, 2010.

34. LUO Zh., SUN O.J., XU H. A comparison of Species Composition and Stand Structure between Planted and Natural Mangrove Forests in Shenzhen Bay, South China. Journal of Plant Ecology, 3 (3), 165, 2011.

35. HEZAGY A.K., ALI A.A., KHADR F.G., AZAB E.M. Sitedependent variation in populations of Avicennia marina (Forssk.) Vierh in Southern Sinai, Egypt, 2002.
36. BERGER U., RIVERA-MONRO V.H., DOYLE T.W., DAHDOUH-GUEBAS F., DUKE N.C., FONTALVOHERAZO M.L., HILDENBRANDT H., KOEDAM N., MEHLIG U., PIOU C., TWILLEY R.R. Advances and limitations of individual-based models to analyze and predict dynamics of mangrove forests: A Review. Aquatic Botany, 89, 260, 2008.

37. NAZIM K., AHMED M., UZAIR-KHAN M., KHAN N., WAHAB M., FAHEEM M.An assessment of the use of Avicennia marina Forsk Vierh, to reclaim water logged and saline agricultural land. Pakistan Journal of Botany, 42 (4), 2423, 2010.

38. SAID W.M., EHSAN N.O.M. Morphological and molecular evidences among four hetero forms of Avicennia marina (Forssk) Vierh. J. Am. Sci, 6, 843, 2010.

39. AKRAM A., ALFARHAN A., ROBINSON E., Aldjain I.Pattern of survival and mortality of mangrove populations grown at Al-Jubail Area (Saudi Arabia) of the Persian Gulf. Am. J. Agri. \& Biol. Sci. 3 (3), 610, 2008v

40. AHMED E., ABDEL-HAMID K.A. Zonation pattern of Avicennia marina and Rhizophora mucronata along the Red Sea Coast, Egypt. WASJ, 2 (4), 283, 2007.

41. DISSANAYAKE N., CHANDRASEKARA U. Effects of Mangrove Zonation and the Physicochemical Parameters of Soil on the Distribution of Macro benthic Fauna in Kadolkele Mangrove Forest, a Tropical Mangrove Forest in Sri Lanka. Advances in Ecology. Volume 2014, Article ID 564056, 13, 2014.

42. ALMULL L. Soil Site Suitability Evaluation for Mangrove Plantation in Kuwait. 20 Applied Sciences Journal, 22 (11), 1644, 2013 